\title{
Current state and problems of commercial fish- farming development in Russia
}

\author{
Lyudmila Kalinina ${ }^{1}$, and Inga Zelenskaya ${ }^{1, *}$ \\ ${ }^{1}$ Institute of Economics, Management and Applied Informatics, Irkutsk State Agrarian University, \\ 664038, 59 Timiryazev str., settlement Molodezhny, Russia
}

\begin{abstract}
Russia, like no other country in the world, has a huge potential for fish-farming development. According to data of different authors, in Russia from 12 to 16 million hectares of water areas of inland water bodies are suitable for fish-farming. Aquaculture farms potential in Russia is estimated at, at least, 2-3 million tons. It should be borne in mind, however, that our statistics do not take into account the so-called micro water bodies with an area of less than 1 hectare. The Department of Economics and Accounting in Agroindustrial Complex of the Irkutsk State Agrarian University in collaboration with Ministry of Agriculture of the Irkutsk Region carried out a study of aquaculture production state, identified factors that hampered its development, gave recommendations on use of forms of state support for agricultural aquaculture producers. The article is devoted to the current state and problems of commercial fishfarming development in Russia, including main aquaculture objects cultivated in Russia and its potential species; volume of catching aquatic biological resources and production of aquaculture products in Russia from 2007 to 2016 and main directions of state support for this sector.
\end{abstract}

Russia's fishery complex has always played a key role in country's economy, but for many years fish products provision has been carried out through fishing: first in the inland seas, and then in the oceans. Fish-farming development was given a secondary role, which determined its weak development at the present time, which does not correspond to the potential industry opportunities [1-3].

Russia has the world's largest water fund of inland waters and seas coastal waters, which includes 22.5 million ha of lakes, 4.3 million ha of water reservoirs, 0.96 million ha of multifunctional agricultural reservoirs, 142.9 thousand ha of ponds and 523 thousand $\mathrm{km}$ of rivers. Length of the coastline is about 60 thousand $\mathrm{km}$, while marine areas in the Barents, White, Azov, Black, Caspian and Far Eastern seas, suitable for housing mariculture complexes, are about 38 thousand $\mathrm{km} 2$.

There are 295 typical freshwater fish species in the waters of the Russian Federation. Representatives of 87 fish species are noted in commercial catches in rivers, lakes and reservoirs. Artificial breeding objects in fresh waters of Russia are representatives of 48 fish species, 3 species of crustaceans, and 12 species of marine hydrobionts (Table 1).

* Corresponding author: klausinga@ mail.ru 
Table 1. The main aquaculture objects, cultivated in Russia.

\begin{tabular}{|l|c|c|}
\hline $\begin{array}{c}\text { Types of } \\
\text { objects }\end{array}$ & Freshwater species: & Marine species: \\
\hline \multirow{4}{*}{$\begin{array}{l}\text { Main } \\
\text { objects: }\end{array}$} & Cyprinus carpio & Salmo salar \\
\cline { 2 - 3 } & Plant-eating fishes & Pectinidae \\
\cline { 2 - 3 } & Oncorhynchus mykiss, Salmo trutta & Apostichohus japonicas \\
\cline { 2 - 3 } & Coregonus peled & Ostreidae \\
\cline { 2 - 3 } & Coregonus & Echinoidea \\
\hline \multirow{3}{*}{$\begin{array}{l}\text { Prospective } \\
\text { objects: }\end{array}$} & Acipenser baerii & Mytilus \\
\cline { 2 - 3 } & Sander lucioperca & Psetta maeotica \\
\cline { 2 - 3 } & Siniperca chuatsi, Morone saxatilis & Mugilidae \\
\cline { 2 - 3 } & Stenodus leucichthys & Dicentrarchus labrax \\
\cline { 2 - 3 } & Salvelinus lepechini & Sciaenidae \\
\hline
\end{tabular}

More than 40 breeds, crosses and types of Cyprinidae, Salmonidae, Acipenseridae, Coregonidae and other fish species that are adapted to breeding in various zonal-climatic and technological conditions are cultivated in industrial fish-farming in Russia (Table 2) $[4,5]$.

A special reserve for aquaculture (fish-farming) development in Russia is the formation of new fish-farming plots and their provision for use.

Taking into account the potential of suitable water areas for accelerated development of this type of activity, active work using system scientific approach and geoinformational analysis methods is carried out to determine suitable for aquaculture implementation water bodies and their parts.

Based on results of the analytical work conducted by the Federal Fisheries Agency, it has been possible to implement aquaculture (fish-farming) on an area of more than 250,000 ha.

Table 2. Fish-farming objects included in the State Register of selection achievements admitted to use in the Russian Federation.

\begin{tabular}{|c|c|c|c|c|c|}
\hline \multirow{2}{*}{ Fish species } & \multicolumn{5}{|c|}{ Selection achievements } \\
\cline { 2 - 6 } & breeds & types & crosses & $\begin{array}{c}\text { Domesticated } \\
\text { forms }\end{array}$ & total \\
\hline Cyprinus carpio & 14 & 2 & 2 & & 18 \\
\hline $\begin{array}{c}\text { Oncorhynchus } \\
\text { mykiss }\end{array}$ & 7 & & 1 & 2 & 7 \\
\hline $\begin{array}{c}\text { Hypophthalmicththys } \\
\text { molitrix, Aristichthys } \\
\text { nobilis }\end{array}$ & 2 & 1 & 5 & 11 \\
\hline $\begin{array}{c}\text { Acipenseridae } \\
\text { Coregonus peled }\end{array}$ & 5 & & & 1 & 2 \\
\hline $\begin{array}{c}\text { Oreochromis } \\
\text { Mylopharingodon } \\
\text { piceus, }\end{array}$ & 1 & & 2 & 2 \\
\hline \begin{tabular}{c} 
Ctenopharyngodon \\
\hline
\end{tabular}
\end{tabular}




\begin{tabular}{|c|c|c|c|c|c|}
\hline Fish species & \multicolumn{5}{|c|}{ Selection achievements } \\
\hline idella & & & & & \\
\hline Total & 30 & 2 & 4 & 10 & 46 \\
\hline
\end{tabular}

In Russia, since the early 1990s, there has been a significant decline in the fish-farming production. By 1996, in comparison with 1989, fish production decreased by 4 times. That situation in the industry was stabilized only by 1999 , when a positive dynamics in the growth of fish products was reached. In 2016, the volume of harvest (catch) of aquatic biological resources in Russia amounted to 4657.6 thousand tons (Table 3).

Table 3. The volume of harvest (catch) of aquatic biological resources and aquaculture production in Russia, thousand tons.

\begin{tabular}{|c|c|c|c|}
\hline \multirow{2}{*}{ Years } & \multicolumn{3}{|c|}{ Indicators } \\
\cline { 2 - 4 } & $\begin{array}{c}\text { Harvest (catch) of } \\
\text { aquatic biological } \\
\text { resources - total }\end{array}$ & $\begin{array}{c}\text { Aquaculture } \\
\text { production }\end{array}$ & $\begin{array}{c}\text { Proportion of aquaculture in } \\
\text { total harvest (catch) of aquatic } \\
\text { biological resources, \% }\end{array}$ \\
\hline 2007 & 3438 & 105,5 & 3,1 \\
\hline 2008 & 3336 & 115,4 & 3,5 \\
\hline 2009 & 3801 & 116,6 & 3,1 \\
\hline 2010 & 4028 & 120,4 & 3 \\
\hline 2011 & 4265 & 128,8 & 3 \\
\hline 2012 & 4270 & 144,9 & 3,4 \\
\hline 2013 & 4281 & 154,9 & 3,6 \\
\hline 2014 & 4236 & 162,3 & 3,6 \\
\hline 2015 & 4457 & 160 & 3,7 \\
\hline 2016 & 4658 & 174 & $X$ \\
\hline 2016 to & 135,4 & 164,9 & \\
\hline $2007, \%$ & & & \\
\hline
\end{tabular}

The main share of harvest (catch) was in the Far Eastern fishery basin $(66.9 \%, 3114.2$ thousand tons) and the Northern fisheries basin (12.2\%, 566.9 thousand tons). In the Baikal fishery basin, where the Irkutsk region is territorially included, the catch was 3.9 thousand tons or $0.08 \%(91.0 \%$ by 2015$)$.

Commercial aquaculture production in the Russian Federation in 2016 was 174.0 thousand tons. Compared with 2007, production increased by $64.9 \%$. However, the aquaculture production share in the total harvest (catch) of aquatic biological resources was only $3.7 \%$ in 2016 , while in China this parametr is over $70 \%$, in India - 50\%, in Norway almost $40 \%$.

The main volume of commercial fish grown in Russia are Cyprinidae (its share is 65\%), Salmonidae (24\%), share of other species is $11 \%$ [6-10]. Bulk was produced on small- and medium-sized enterprises (Table 4).

The main volume of aquaculture production is mainly produced in the Southern and North-Western Federal Districts, where were produced 63.5 thousand tons and 37.2 thousand tons of commercial fish in 2016, which was $36.5 \%$ and $21.4 \%$, respectively, from the all-Russian production. 
The largest volumes of production (by regions of the Russian Federation in 2016) were achieved in the Rostov region - 20.3 thousand tons, the Krasnodar region - 18.8 thousand tons, the Astrakhan region - 16.7 thousand tons, the Karelia region -14.7 thousand tons, the Murmansk region -12.6 thousand tons, the Stavropol region -10.8 thousand tons.

Table 4. Grouping of aquaculture enterprises in Russia by annual production in 2016.

\begin{tabular}{|c|c|}
\hline $\begin{array}{c}\text { Commercial aquaculture } \\
\text { production on enterprises }\end{array}$ & Share in total number of enterprises, $\%$ \\
\hline less than 50 tons per year & 67 \\
\hline $50-100$ tons per year & 19 \\
\hline $101-1000$ tons per year & 12 \\
\hline more than 1000 tons per year & 2 \\
\hline
\end{tabular}

The development of commercial aquaculture by federal districts is characterized by following indicators. The production leader in 2016 was the Southern Federal District 63.5 thousand tons of commercial aquaculture. The largest products volume was grown in the Rostov region (20.5 thousand tons) and the Astrakhan region (20 thousand tons). High indicators had the Krasnodar region (20 thousand tons). The next largest aquaculture producer wasthe North-West Federal District (37.2 thousand tons). The leader in the NorthWest Federal District is the Karelia region, with 14.7 thousand tons. In addition, the high outputs are in Murmansk (13.7 thousand tons) and Leningrad regions (7.6 thousand tons). The third largest producer of commercial aquaculture products was the Central Federal District -24.8 thousand tons. The leader in this district is the Belgorod region (6.4 thousand tons). The average level of production are reached in the North Caucasus Federal District (16.3 thousand tons), the Volga Federal District (12.2 thousand tons), the Far Eastern Federal District (6.9 thousand tons), the Urals Federal District (5.8 tons), and the Siberian Federal District (5.8 thousand tons).

In the Siberian Federal District, the leaders in production of commercial aquaculture are the Krasnoyarsk region (1438 tons of fish were grown in 2016), the Novosibirsk region (876 tons), and the Kemerovo region (732 tons). Salmonidae (Salmo trutta) are prevail among the species of aquatic bioresources - $36 \%$ of total aquaculture production. Cyprinidae (Cyprinus carpio, Tinea tinea) are 34\%, Coregonidae (Coregonus peled) - 12\% and others (Acipenser, Huso huso $\times$ Acipenser ruthenus, Esox lucius) $-18 \%$. The type of farms in the district is dominated by industrial aquaculture enterprises $(53 \%)$, pond and pasture aquaculture enterprises together constitute $47 \%$. In terms of production, $83 \%$ of farms produce less than 50 tonnes of commercial aquaculture per year, $7 \%$ - from 50 to 100 tonnes per year, 10\% - over 100 tonnes per year (Table 5).

Table 5. Characteristics of fish-farming development in the Siberian Federal District in 2016.

\begin{tabular}{|c|c|}
\hline $\begin{array}{c}\text { Characteristics of fish-farming development in } \\
\text { the Federal District }\end{array}$ & Indicators \\
\hline Number of commercial aquaculture enterprises & 126 \\
\hline $\begin{array}{l}\text { Commercial aquaculture production in } 2016, \\
\text { thousand tons }\end{array}$ & 5.6 \\
\hline Place in the Russian Federation in terms of output & 8 \\
\hline $\begin{array}{l}\text { The share of the District in the all-Russian } \\
\text { production, } \%\end{array}$ & 3.3 \\
\hline
\end{tabular}




\begin{tabular}{|l|c|}
\hline \multicolumn{1}{|c|}{$\begin{array}{c}\text { Characteristics of fish-farming development in } \\
\text { the Federal District }\end{array}$} & Indicators \\
\hline The main types of famed aquatic bioresources & $\begin{array}{c}\text { Salmo trutta } \\
\text { Cyprinus carpio } \\
\text { Coregonus peled }\end{array}$ \\
\hline $\begin{array}{l}\text { Regions of the Russian Federation - leaders in the } \\
\text { production of aquaculture in the federal district }\end{array}$ & $\begin{array}{l}\text { Krasnoyarsk region } \\
\text { Novosibirsk region } \\
\text { Kemerovo Region }\end{array}$ \\
\hline $\begin{array}{l}\text { Volume of governmental support (the volume of } \\
\text { subsidies in 2015 - 2016), million rubles }\end{array}$ & 186.0 \\
\hline
\end{tabular}

Leading suppliers of fish seeding material are the Central Federal District (8.4 tons), the Northwestern Federal District (7.1 tons), and the Southern Federal District (9.3 tons).

The Government of the Russian Federation, Ministry of Agriculture of the Russian Federation, Federal Fisheries Agency make decisions that are aimed at increasing the production of aquaculture. Law on aquaculture was adopted in 2013, which laid legal basis for the development of industry; resolutions and orders to ensure implementation of this law were also adopted; ministerial program for development of aquaculture was prepared [11].

These steps made it possible to increase the production of marketable fish output in 2014. According to data of the head of the Federal Fisheries Agency, I. V. Shestakov, Russia annually produces about 160 thousand tons of commercial fish, which is less than $4 \%$ of the total Russian catch, while the potential capacity of industry is quite high [12]. So, the largest share in fish imports by Russia - about $20 \%$ of total volume - is made by fresh and chilled fish, which gives aquaculture industry wide opportunities for import substitution [13-15].

Increase in volume of commercial fish largely depends on level of governmental support, increasing investment attractiveness of industry, consumer demand and other factors.

In the ministerial program, by 2020 , the production of commercial aquaculture is expected to double to 330 thousand tons. At the same time, according to scientists, possible volume of production can be increased up to 700 thousand tons.

Reserve for increasing production of aquaculture outputs is seen in geography expansion of fish farms. Natural and climatic conditions of country make it possible to develop fish culture in all regions of the Russian Federation. So, in regions of Southern Federal District, almost all types of fish farming can be developed: pond, industrial (trout farming in foothill areas), pasture aquaculture in lakes, estuaries and reservoirs. In the North-West Federal District, it is promising to conduct pasture fish farming and industrial (cage fish culture) in cultivation of salmon and whitefish species. The Far Eastern Federal District may become a leader in cultivation of marine hydrobionts. The Siberian Federal District has largest fund of freshwater water objects, where it is possible to develop pasture and industrial aquaculture. At the same time, the district is rich in geothermal sources, which makes industrial fish farming promising and economically prospective. It is also possible to grow cold-water (mainly whitefish) and warm-water (sturgeon, carp) fish species, which expands the sales markets.

Also, a system of governmental support for subjects of aquaculture and commercial sturgeon breeding is developing.

The main objective of this system is to provide and distribute subsidies from federal budget to budgets of regions of the Russian Federation to recover part of paying interest costs on loans received in Russian credit institutions for commercial aquaculture (commodity fish-farming) development, including commercial aquaculture of sturgeon 
species, in accordance with Appendix №5 to the Russian Federation state program "Development of fishery complex," approved by the decree of the Government of the Russia Federation on April 15, 2014, № 314.

The Federal Law of December 14, 2015, №359 “On Federal Budget for 2016” (taking into account optimization of federal budget expenditures for 2016) provides budgetary allocations for implementation of epy State Program part "Development of state support system for aquaculture and commodity sturgeon" in the amount of 396.1 million rubles.

By the decrees of the Government of the Russian Federation № 1439-r of July 7, 2016, and № 1463-r of July 9, 2016, distribution of subsidies granted in 2016 from federal budget to budgets of regions of the Russian Federation for co-financing expenditure obligations of regions of the Russian Federation related to reimbursement part of the costs of agricultural producers to pay interest on loans received from Russian credit institutions to develop aquaculture (fish-farming) and commercial sturgeon under the State Program's parts "Aquaculture Development" and "Development of sturgeon farming" were approved.

According to above-mentioned decree, agreements on granting subsidies between the Russian Federal Fisheries Agency and regional authorities of Novgorod, Kaluga, Murmansk, Leningrad, Karelia, Dagestan, Primorsky, and Krasnoyarsk regions were concluded by July 15, 2016.

A number of regions of the Russian Federation have begun to develop and implement their own programs to support the fishery industry, in particular the aquaculture industry. Thus, the Government of Murmansk region has developed the Governmental Program "Development of the Fisheries Complex," which provides for governmental support to aquaculture enterprises, by providing subsidies to producers to refund a portion of interest rate on loans received from Russian credit institutions for commercial aquaculture (commercial fish farming) development. Similar programs operate in Kostroma, Astrakhan, Chelyabinsk, Belgorod, Krasnoyarsk, Buryatia, Komi, Khakassia, and other regions, which provide for various directions of governmental support for aquaculture industry.

On basis of our study, to increase the interest of agricultural producers in increasing aquaculture production, it is proposed to provide subsidies for:

- Reimbursement of part of paying interest costs on investment loans received for development of fish farming;

- Reimbursement of part of costs for payment of interest on loans received for construction, reconstruction, modernization of fish farming and (or) fish processing;

- Reimbursement of part of costs for payment of interest on loans received for construction and reconstruction of freezing capacities, capacities for production of processed fish products;

- Sesign, reconstruction, overhauling of hydraulic facilities;

- Purchase of machinery and equipment used in aquaculture, including the purchase of installations for closed water cycle;

- Performance of works (provision of services) for supply of water to fishery water bodies;

- Reimbursement of part of costs of sold aquaculture products grown by intensive technologies;

- Reimbursement of part of costs for sold fish seeding material (for fish farms), as well as for purchased fish seeding material (for fish farms);

- Purchase of feed.

Implementation of recommendations above will solve the problem of increasing the aquaculture production in Russian regions. 


\section{References}

1. V. S. Zakharov, Condition and perspectives of freshwater aquaculture development, Trade fish breeding in Russian Federation and its development tendention, 39 - 42 (2013)

2. F. Teletchea, P. Fontaine, Fish and Fisheries, 15, 181-195 (2014)

3. P. Gros, Cahiers d'Etudes et de Recherches Francophones, Agricultures, 23, 4-17 (2014)

4. M. K. Glubokovskiy., I. V. Burlachenko, Conference Regarding Aquaculture Fevelopment in the Russian Federation: Reports, Materials, 13 (2014)

5. V. Y. Katasonov, V. N. Dementyev, A. A. Kochetov Condition and perspectives of freshwater aquaculture development, Organization of tribal breeding in pisciculture, 42-47 (2013)

6. M. Yabanli, A. Yozukmaz, Y. Alparslan, Ü. Acar, Journal of Food, Agriculture and Environment, 12, 165-168 (2014)

7. D. Steinhagen, V. Jung-Schroers, M. Adamek, CAB Reviews: Perspectives in Agriculture, Veterinary Science, Nutrition and Natural Resource, 11, 041 (2016)

8. M. Tzanova, V. Atanasov, G. Beev, T. Dinev, E. Valkova, B. Zaharinov, Journal of Central European Agriculture, 18, 369-387 (2017)

9. M. Uspenskaya, M. Kremenevskaya, K. Volkova, O. Sosnina Agronomy Research, 14, 604-613 (2016)

10. E. E. Onumah, B. Brümmer, G. Hörstgen-Schwark, Agric. Econ., 56, 79-88 (2010)

11. S. Siddiki, J. Kim, W.D. Leach, Public Administration Review, 77, 863-874 (2017)

12. I. V. Shestakov, Domestic fishfarming has a huge potential and significant opportunities for growth (http://fish.gov.ru/press-tsentr/novosti/6950-intervyu-ilishestakova-zhurnalu-prodovolstvennaya-bezopasnost)

13. L. Smutka, J. Spicka, N. Ishchukova, R.Selby, Agric. Econ., 62, 493-506 (2016)

14. I. Benesova, M. Maitah, L.Smutka, K. Tomsik, N. Ishchukova, Agric. Econ., 63, 318330 (2017)

15. G. Parisi, G. Terova, L. Gasco, G. Piccolo, A. Roncarati, V. M. Moretti, G. Centoducati, P. P. Gatta, A. Pais, Reviews in Fish Biology and Fisheries, 24, 15-73 (2014) 